\title{
実践研究
}

\section{校内の連携・支援体制づくりを目指すコーディネーターの役割 個別の指導計画の作成と実践をとおして}

\author{
佐 藤 公子*・八幡ゆかり**
}

筆者らは、小学校の障害児学級に在籍する児童に対して個別の指導計画を作成し、実践し た。その際、コーディネーターが、校内の連携・支援体制づくりに取り組んだ。そして、連 絡調整役としてのコーディネーターの役割について検討した。その結果、対象児童の変容は もとより、教職員、保護者の意識の変容がみられ、校内の連携・支援体制が強化された。こ のことから、コーディネーターの役割として、教師間や保護者との連絡調整にとどまらず、 校内の連携・支援体制づくりを目指すことの重要性が示唆された。また、第三者としての客 観性を保ちながらも、教師集団の一員として協働意識をもって臨むことの必要性が明らかに なった。

キー・ワード：個別の指導計画 コーディネーター 校内の連携・支援体制づくり

\section{I . はじめに}

特別支援教育では、障害のある览童生徒等 1 人 1 人 について、個別の教育支援計画の作成が提言されてい る。その際、学校内および関係機関や保護者との連絡 調整役としての、特別支援教育コーディネーター（以 下「コーディネーター」という) の役割が重要視され ている。また、個別の指導計画は、学校全体の教育計 画のもとに、児童 1 人 1 人の教育的ニーズに対応して 指導の方法や内容の明確化を図るものであり、学校で のきめ細かな指導を行うために有意義なものと考えら れている（特別支援教育の在り方に関する調查協力者 会議, 2003)。個別の指導計画の作成における課題とし て、安藤（2002）は複数の教師が関与すること、笠原 （2002）は教師間の協力体制づくりを指摘し、両者と もに連携・支援体制づくりを挙げている。

ところで、個別の指導計画は、1999 年 3 月に告示 された盲学校、龍学校および養護学校学習指導要領に おいて、自立活動の指導と重複障害者の指導にあたつ て作成するものと規定された。そして、小学部および 中学部は 2002 年度から完全実施されており、高等部 については、2003 年度から学年進行により実施され

* 徳島市津田小学校

** 鳴門教育大学学校教育学部
ている。

しかし、障害児学級では個別の指導計画の作成が義 務づけられていないため、実施していない学級が多 い。共同研究者の 1 人である佐藤が所属していた $\mathrm{H}$ 小学校においても、個別の指導計画の作成が課題とな っている。さらに、筆者らの知る限りでは、コーディ ネーターがかかわった個別の指導計画の実践研究は見 当たらない。

そこで、筆者らは、 $\mathrm{H}$ 小学校を取り上げて、校内 の連携・支援体制づくりを視野に入れた個別の指導計 画を作成し、安藤、笠原らが指摘している、「複数の 教師で取り組む」、「教師間の協力体制づくり」などを 目指すことにした。そして、校内の連携・支援体制づ くりにおけるコーディネーターの役割について検討す ることにした。

\section{II. 方 法}

\section{1. 研究対象}

研究対象学級は、H 小学校 $\mathrm{N}$ 障害児学級 (児童数 2 名、担任教師 2 名)。対象児 $\mathrm{A}$ 児は、指導開始時 5 年生の女児で、水頭症、てんかん、軽度知的障害があ る。対象児 $B$ 児は、指導開始時 6 年生の男児で、て んかん、重度知的障害がある。 


\section{2. 研究の手続き}

共同研究者の 1 人である佐藤がコーディネーターと して、次の 3 点を行う。(1) 対象児の個別の指導計画 を作成し、校内の教職員ならびに保護者に提示する、

(2) 実践においては、個別の指導計画の指導実践によ る対象児の変容の有無について、学校外の共同研究者 である八幡と協議して検討する、(3) 教職員や保護者 に聞き取り調查（意識調査）を実施し、個別の指導計 画の実践によって意識の変容がみられたか否か、八幡 と協議して検討する。

\section{（1）個別の指導計画の作成}

1 ）個別の指導計画作成前の指導、連携・支援体 制の把握：コーディネーターが、前年度の障害児学 級担任と今年度の障害児学級担任、養護教諭、管理職 者に聞き取り調查を行い、現状と課題を明らかにす る。

2 ）児童の実態把握（ベースライン）：コーディ ネーターが 2002 年 11 月〜2003 年 3 月まで、(1) 行動 観察、(2) 前年度の障害児学級担任と保護者への聞き 取り調查、(3) 諸検査 (WISC-III、K-ABC 等) を行う。

3 ）長期目標、短期目標预よび指導内容・方法の 決定：コーディネーターが作成し、障害児学級担任、 保護者と協議し決定する。

(2) 個別の指導計画の実践

1) 指導期間：第 1 期（以下「1 学期」とする）の 指導実践は 2003 年 4 7 月まで、第 2 期（以下「2 学 期」とする）は 2003 年 9 11月までとする。

2 ) 評価：短期目標の達成度の評価は、学習面 は、佐藤と障害児学級担任が児童の実態（プロフィー ル表に記載された指導開始前の児童の様子）をべース ラインとし、5 段階で評価する。生活場面は、筆者ら がベースラインと比較し、教職員への聞き取り調査の 結果を合わせて総合的に評価する。また、連携・支援 体制に対する評価は、教職員からの聞き取り調査（教 職員の役割：連携・支援内容）における自己評価の結 果を比較し、達成度をみていく。それに、保護者、対 象児（A 児）への聞き取り調査の結果を合わせて総 合的に評価する。 5 段階評価は、5：たいへんよくで きた、4：よくできた、3：できた、2：あまりできな かった、1：できなかった、とする。

（3）コーディネーターの役割についての検討： 1 学期、2 学期の指導実践の結果および教職員への聞 き取り調查の結果から検討する。

\section{III. 結 果}

\section{1. 個別の指導計画の作成におけるコーディネータ 一の活動の実際}

(1) 個別の指導計画作成前の指導、連携・支援体 制の把握：聞き取り調査の結果、指導面では、児童 の実態把握、指導内容や方法、障害理解教育、人権教 育の推進が課題となっていた。連携・支援体制面で は、障害児学級担任間の引継ぎ、通常学級担任ならび に養護教諭との連携、保護者の願いについての把握が 課題となっていた。

(2) 個別の指導計画の作成：コーディネーターが 作成した原案をもとに、障害児学級担任と協議し、修 正した。次に、保護者を交えて、児童の実態を踏まえ た目標設定の理由、指導内容・方法等について説明 し、同意を得て個別の指導計画を決定した。

1）児童の実態把握（ベースライン）：コーディネ ーターが、児童の実態をプロフィール表（Table 1, Table 2) にまとめた。生活、学習、社会性について 概括すると、次のとおりであった。

A 児は、学校で頻繁に発作が起こり入退院を繰り 返すようになってから、文字や絵がうまくかけなくな るなど能力面に対する心配、発作による体調変化や発 作への恐怖心、排尿の失敗回数の増加による不安感が 強くなっていった。そのため、学習持続時間が数分程 度と短くなる、学習を嫌がり席に着こうとしない、交 流学級での学習や行事などに参加したがらない、母親 への甘えが強く送迎時に抱きついて離れょうとしない など、行動の変化がみられた。心理検査の結果、 WISC-III は全検查 IQ 53、言語性 IQ 66、動作性 IQ 48 で個人内差が認められた。K-ABC は認知処理過程 78、継次処理、同時処理、習得度の間に有意差は認め られなかった。 S-M 社会生活能力検查は、社会生活 年齢が 5 歳 8 か月であった。

B 児は、衣服の着脱やボタンかけがほぼ自分でで き、語菓が増え発音がはっきりしてきた。学習は、自 分のしたいことや興味のあることには取り組み、歌を 聴く、絵を描くなどができた。しかし、着席して指示 された課題を遂行すること、教師の指示や声かけで行 動することは難しかった。嫌なときや気分がのらない ときは、すぐ床に横になったり座り込んだりして動か なくなった。2002 年 11 月〜2003 年 3 月までの間に、 多いときで 1 日のうちに複数回このような光景が繰り 返された。B 児は心理検査が測定不能であったため、 太田の Stage 評価法を用いた。Stage III-1 前期の段 階であった。S-M 社会生活能力検查は、社会生活年 
校内の連携・支援体制づくりを目指すコーディネーターの役割

Table 1 A 児 個別の指導計画表（2003 年 4 月作成）

1. プロフィール表

〈配慮事項等〉・体調の把握に努める. 顔色, 表情, 反応の様子などをきめ練かく観察する. 疲労が大きいとき,いつも と状態が違うときなどは, すぐ保護者に連絡する。

・体調に合わせて, 休憩をとる, 学習内容を変更する, など柔軟に対応する.

・教室移動, トイレなど常にそばに付き添い, 安全の確保に努める. 階段の昇降は特に注意する。

・発作時は, 管理職者, 養護教諭, 保護者に連絡し, 適切に対処する.

・保護者, 医療機関との連携を密にする.

〈諸 検 査〉 WISC-III : CA 9：8, FIQ : 53, VIQ : 66, PIQ : 48, VC : 73, PO : 54, FD : 56, PS : 50

$\mathrm{K}-\mathrm{ABC}: \mathrm{CA} 9: 8$, 認知処理過程 78 , 継次処理 84 , 同時処理 76 , 習得度 75

MEPA：CA 9：8, 運動・感覚：第 4 ステージ, 言語：第 4 ステージ, 社会性：第 4 ステージ

S-M 社会生活能力検查 : SA $5: 8(\mathrm{SQ} 59)$ 身辺自立 $5: 5$, 移動 $3: 9$, 作業 $5: 1$, 意志交換 $7: 8$, 集団 参加 $5: 5$, 自己統制 $6: 10$

〈本児のよさ〉・思いやりがあってやさしい. 親や友だち，担任を気遣いやさしい言葉をかける．動植物を大切にする.

・気持ちのよいあいさつや，はきはきとした受け答えができる. 思ったことや経験したことを伝えること ができる.

・感受性が豊かで, 想像力を働かせることができる，言葉や体でのびのび表現することができる.

・体調がよいときは，空ふきや床ふきなどを熱心にする. 体を動かすことが好きである.

〈学校生活の様子〉

学 習：ひらがなや片仮名, 簡単な漢字の読み書きができる. 2 年生程度の教材文の大まかな内容をとらえるこ とができる. 30 までの数の数唱がほぼできる. 具体的操作で 5 までの数のかぞえ足しがほぼできる. 時, ○時半の時計がよめる.曲に合わせて体を動かす, 歌を歌うなど音楽が好きである. 文字や絵が雑 になってきた. 学習全般を嫌がるようになってきた. 席に着こうとしないことがある. 体調により, 学 習に集中できるのは 5〜10 分ぐらい, 物を作るときは, 20〜30 分ぐらいである.

生 活：着替え，ランドセルの片づけ，歯磨き，排泄などの身の回りのことが自分でできる.排尿の予告ができ ず,間に合わないときがある.失敗を隠すことがある.

健 康：日によって時間によって体調が変わる. 発作の時間や様子は特定できない. 足元がふらつくことがあ る. 体温調節ができない. 姿勢の保持（特にいすに座るとき）が難しい. 指先の力の調節，目と手の協 忘が十分でない.

対人関係：教師とのかかわりは良好で，自分から話しかけることができる，友だちに話しかけたり，かかわったり することは苦手である. 交流学級での学習や行事などへの参加が負担になっている.

行 動: 場面の切り替えが苦手になってきた. 好きなことをいつまでも続けようとする. 位置関係の把握が難し い. 壁，柱，段差など危険物を回避できないことがある.

〈家庭生活の様子〉体調がよいときはおもちゃを出してよく遊ぶ. 体調がよくないときはテレビやビデオを見る，本が 好きでよく読む. 料理の手伝いをよくする. ホットケーキ, ピザパン，野菜切りなどが得意. 片づけが 苦手.

〈保護者の願い〉 身なり，食事中の姿勢，排便など基本的な生活ができるよう指導してほしい. 最後までやり遂げるよ うになってほしい. 力の入れ具合や細かい調節ができるようになってほしい. 人前で甘えないようにな ってほしい. 将来は, 友だちがしているような普通の生活ができたらいいなと思う. 中学校は, 本人に 合うところ, 発達を促せるところがよい.

〈教師の願い〉 安心して楽しい学校生活が送れるようにしたい. 学習に興味をもって取り組むことにより自信をつけ, もっている力が発揮できるようになってほしい. 自分から友だちに話しかけ，かかわりをもつことがで きるようになってほしい.

※本表は，実際の書式とは異なる，また，内容も略式である。 
Table 2 B 児 個別の指導計画表（2003 年 4 月作成）

1. プロフィール表

〈配慮事項等〉・体調の把握に努める. 顔色, 表情, 反応の様子などをきめ細かく観察する. 疲労が大きいとき, いつも と状態が違うときなどは，すぐ保護者に連絡する.

・体調に合わせて，休憩をとる，学習内容を変更する，など柔軟に対応する.

・教室移動, トイレなど常にそばに付き添い, 安全の確保に努める. 階段の昇降は特に注意する.

・発作時は, 管理職者, 養護教諭, 保護者に連絡し, 適切に対処する.

・保護者, 医療機関との連携を密にする.

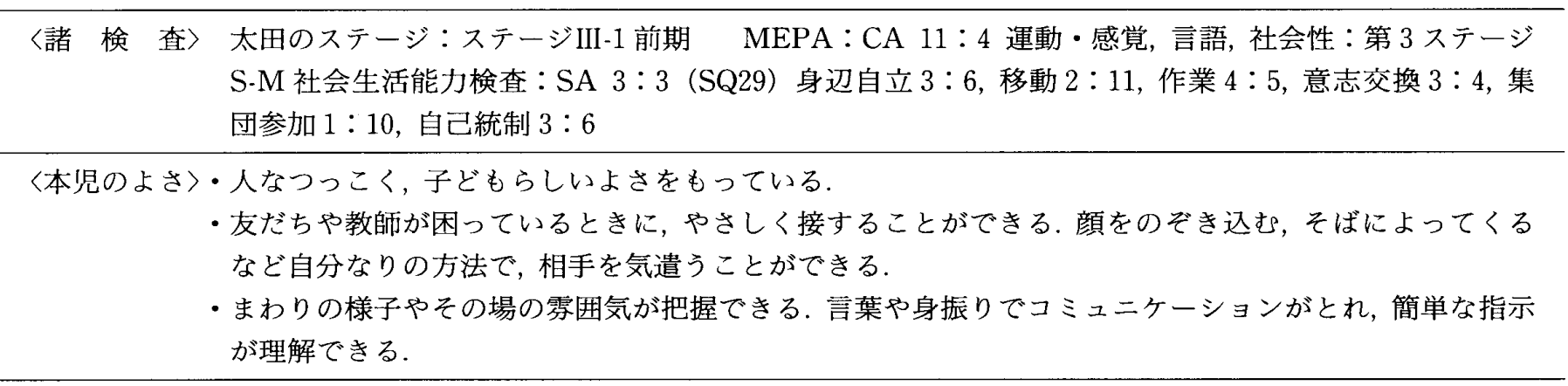

〈学校生活の様子〉

学 習：語彙が増え，発音もはっきりしてきた. 2 語文を話すことができる. 10 までの数字がほぼ読める. 丸，三 角, 四角の区別ができる. 具体物の大小, 長短がわかる. 歌を聴くことが好きで, 簡単な絵を描くこと ができる.はさみで大体の形を切ったり，セロテープで貼ったりすることができる. 教師の指示や声か けで学習や活動に取り組むことは難しい.

生 活：衣服の着脱, 歯磨き, ボタンかけ, 学用品の出し入れ, ロッカーへの片づけほほほ自分でできるが, 気 分に左右される. 尿意や便意を伝えることができる. 排便の後始末は手伝いが必要である.

健 康：集中したり,がんばったりした後は疲れが出やすい. 学校での発作はなくなった. ほんやりする, 目線 がうつろになる, 目がすわる感じになるときがある. 性器いじりをすることがある.

対人関係：教師とのかかわりは良好．そのときの気分により指示を聞かないことが多い. 相手が自分にかかわって くれることを喜ぶ. 教師の気を引く行動を取ることがある. 友だちに直接話しかけたりかかわりをもつ たりすることは少ない.

行動：場面の切り替えが苦手で, 活動を途中でやめる, 他の活動に切り替えるなどは難しい. 嫌なときや気分 がのらないときに，座り込んだり横になったりする．常に物（こいのぼり）を握っている．紙などをひ らひらさせることを好む. 朝会, 集会などで, 奇声を発することがある. 柱, 壁, 段差など危険物を回避 できないことがある.

〈家庭生活の様子〉 休日は, 家族と買い物に行ったり，いろいろな公園へ遊びに行ったりする. 祖父母宅へ遊びに行く. よいことをしたときやほめるときに,「大きな丸」と言いながら大きい丸のサインをすると喜ぶ.

〈保護者の願い〉 季節や月日・曜日, 朝・昼・夜, 左右・上下がわかる. 学校生活の 1 日の流れ, 授業・休み時間のけ じめがわかる. 自分の名前の読み書き（ひらがな）, 数字（1～12）がわかる. 指示がなくても服の着脱, 歯磨き，洗顔ができる. 排便後の始末，くつの着脱，あいさつができる. 集団行動ができ，人に迷惑をか けない. 車など危険な物に気をつけることができる. 将来は, 就労できたらと思う. 無理なようであれ ば, 作業所で仕事ができるようになったらいいなと思う. 中学校進学については, K 養護学校か I 養護 学校を考えている. 発作があるので, 宿泊はさせたくない.

〈教師の願い〉 横になったり座り込んだりしないで, 意思表示ができるようになってほしい. 指示や声かけでスムーズ に活動できるようになってほしい. 好きなことや興味のあることだけでなくさまざまな活動に取り組 み，もっている力が発揮できるようにしたい. 友だちと一緒に活動したり遊んだりするようになってほ しい. 
校内の連携・支援体制づくりを目指すコーディネーターの役割

Table 3 A 児 個別の指導計画表 (2003 年 4 月作成)

2. 目標〈中心課題〉安心して楽しい学校生活を送る.

〈長期目標〉@1．体調の変化に気づき, 必要に応じて周りの教師や友だちに伝えたり助けを求めたりす る. (生活)

2. 学習に意欲的に取り組み，持続時間をのばす（学習)

3. 自分から進んで友だちや教師とかかわる.（社会性）

\begin{tabular}{|c|c|c|c|c|}
\hline 短期目標 & 指導内容 & 方 & $\begin{array}{l}\text { 指導場面 } \\
\text { (担当者) }\end{array}$ & 評価 \\
\hline $\begin{array}{l}\text { (1) 自分の体について理解 } \\
\text { し, 体調の変化を担任に } \\
\text { 伝える. }\end{array}$ & $\begin{array}{l}\text { - 発作の起こるわけや対処の } \\
\text { 仕方がわかる. } \\
\text { - 体調の変化を伝えることを } \\
\text { 知る. }\end{array}$ & $\begin{array}{l}\text { - 養護教諭, 保護者と共通理解を図 } \\
\text { り, 発作の起こるわけや対処の仕 } \\
\text { 方を説明する. (絵本・身振りサ } \\
\text { イン) } \\
\text { ・発作のときは声をかけ安心させ } \\
\text { る. }\end{array}$ & $\begin{array}{l}\text { 体育（保健） } \\
\text { (担任) } \\
\text { 日常生活 } \\
\text { (担任, 佐藤） }\end{array}$ & $1 \sim 5$ \\
\hline $\begin{array}{c}\text { O(2) 休み時間や行事などへ } \\
\text { の参加の前に, 自分から } \\
\text { トイレに行く. }\end{array}$ & $\begin{array}{l}\text {-9 時 } 30 \text { 分, } 10 \text { 時 } 30 \text { 分にト } \\
\text { イレに行く. 失敗したとき } \\
\text { は担任に伝える. } \\
\text { ・行事参加の前にトイレに行 } \\
\text { く. }\end{array}$ & $\begin{array}{l}\text { ・時間が来ても忘れているときは, } \\
\text { 声をかける. (時計の表示) } \\
\text { ・自分からトイレに行けたとき, 失 } \\
\text { 敗を伝えたときはほめる. (ごほ } \\
\text { うびシール) }\end{array}$ & $\begin{array}{l}\text { 日常生活 } \\
\text { (担任, 佐藤) }\end{array}$ & $1 \sim 5$ \\
\hline $\begin{array}{l}\text { (3) 興味をもって学習に取 } \\
\text { り組む。. }\end{array}$ & $\begin{array}{l}\text { ・朝の会や学習で, 体験した } \\
\text { ことや思ったことを話す. } \\
\text { ・5までの数の合成・分解が } \\
\text { でき, 生活の中で使う. }\end{array}$ & $\begin{array}{l}\text { ・「つ・誰が・どうした」や順序 } \\
\text { に気をつけて話すよう促す. } \\
\text { ・具体物などを使って, } 5 \text { までの数 } \\
\text { の合成・分解ができるようにす } \\
\text { る. (ビーズ・造花など) ゲーム } \\
\text { やお手伝いなど, 生活の中で使う } \\
\text { 場面を設定する. }\end{array}$ & $\begin{array}{l}\text { 朝の会, 各教 } \\
\text { 科（担任） } \\
\text { 算数（佐藤） } \\
\text { 日常生活 } \\
\text { (担任, 佐藤） }\end{array}$ & $1 \sim 5$ \\
\hline $\begin{array}{l}\text { (4) 新しい担任に慣れ, 自 } \\
\text { 分から話しかけたり一緒 } \\
\text { に遊んだりする. }\end{array}$ & $\begin{array}{l}\text { ・担任と遊びやゲームを楽し } \\
\text { む. } \\
\text { ・担任と話をする. }\end{array}$ & $\begin{aligned} \text { ・一緒に遊びやゲームを楽しみ, 信 } \\
\text { 頼関係を築く. }\end{aligned}$ & $\begin{array}{l}\text { 日常生活 } \\
\text { （担任） }\end{array}$ & $1 \sim 5$ \\
\hline $\begin{array}{l}\text { (5) } 5 \text { 年生の雾囲気に慣れ, } \\
\text { 特定の友だちと一緒に行 } \\
\text { 動する. }\end{array}$ & $\begin{array}{l}\text { ・交流学習や給食で, 特定の } \\
\text { 友だちと一緒に活動する. }\end{array}$ & $\begin{array}{l}\text { ・学習内容や参加の仕方について, } \\
\text { 交流学級担任と連携を図る. 友だ } \\
\text { ちと話や活動ができるように, 担 } \\
\text { 任が仲立ちをする. }\end{array}$ & $\begin{array}{l}\text { 交流学習 } \\
\text { (担任, 交流 } \\
\text { 学級担任) }\end{array}$ & $1 \sim 5$ \\
\hline
\end{tabular}

※@は最優先目標，○は優先目標. 本表は, 実際の書式とは異なる.

※評価は, 5 たいへんよくできた, 4 よくできた, 3 できた, 2 あまりできなかった, 1 できなかった, の 5 段階の自己評価 とする.

齢が 3 歳 3 か月であった。

2) 目標の設定：児童の教育的ニーズを中心課題 とし、生活、学習、社会性の 3 つの視点加ら、年間目 標として長期目標 1 、長期目標 2 、長期目標 3 を設定 した。短期目標は、長期目標の達成を目指し学期ごと に設定した（Table 3, Table 4)。

A 児の中心課題を、「安心して楽しい学校生活を送 る」に設定した。そして、長期目標 1 を「体調の変化 に気づき、必要に応じて周りの教師や友だちに伝えた
り助けを求めたりする」(生活) とし、発作や排尿の 失敗からくる不安を軽減するために「自分の体につい て理解し、体調の変化を担任に伝える」(短期目標(1)）、 「休み時間や行事などへの参加の前に自分からトイレ に行く」（短期目標(2)）を設定した。長期目標 2 を 「学習に意欲的に取り組み、持続時間を延ばす」(学 習）とし、学習への抵抗感を少なくするために「興味 をもって学習に取り組む」(短期目標(3)）を設定した。 長期目標 3 を「自分から進んで友だちや教師とかかわ 
Table 4 B 児 個別の指導計画表 (2003 年 4 月作成)

2. 目標〈中心課題〉横になったり座り込んだりする行動を少なくする.

〈長期目標〉@1．教師の声かけでスムーズに行動し，横になったり座り込んだりする行動を少なくする． (生活)

2.いろいろな活動をとおして興味や関心を広げ，いすに座って学習に取り組む時間を 徐々にのばす。(学習)

3. 話し言葉や動作，身振りなどで自分から友だちや教師とかかわろうとする。（社会性）

\begin{tabular}{|c|c|c|c|c|}
\hline 短期目標 & 指導内容 & 法 & $\begin{array}{l}\text { 指導場面 } \\
\text { (担当者) }\end{array}$ & 評価 \\
\hline $\begin{array}{l}\text { O(1) 教師の声かけで, ラン } \\
\text { ドセルの片づけ, 給食の } \\
\text { 用意をする. }\end{array}$ & $\begin{array}{l}\text { ・担任の声かけで, ランドセ } \\
\text { ルの中の文房具などを机の } \\
\text { 中に入れ, ランドセルをロ } \\
\text { ッカーに入れる. } \\
\text { ・担任の声かけで, エプロン } \\
\text { 着用, 手洗いをする. }\end{array}$ & $\begin{array}{l}\text { ・声かけで取りかかれないときは写 } \\
\text { 真を見せ, 次の行動や場面を指示 } \\
\text { する. 取りかかれないときは, 補 } \\
\text { 助をする. スムーズにできたとき } \\
\text { はほめる. (写真・ごほうびシー } \\
\text { ル) }\end{array}$ & $\begin{array}{l}\text { 日常生活 } \\
\text { (担任, 佐藤) }\end{array}$ & $1 \sim 5$ \\
\hline $\begin{array}{l}\text { O(2) } 1 \text { 日に } 1 \text { 回は, 着席し } \\
\text { て学習や活動に取り組 } \\
\text { む. }\end{array}$ & $\begin{array}{l}\text { ・着席して, 教師と一緒に好 } \\
\text { きな学習やゲーム, 遊び } \\
\text { (マッチング, パズル, ビー } \\
\text { ズとおし, ペグさしなど) } \\
\text { をする. }\end{array}$ & $\begin{array}{l}\text { ・活動の始めと終わりがわかるよう } \\
\text { にする.（課題かご・終了かご） } \\
\text { ・ゲームや遊びの中で語彙を増や } \\
\text { す. 数えたり, } 1 \text { 対 } 1 \text { 対応をしたり } \\
\text { する場面を設定する. } \\
\text { ・好きな活動を一緒にすることから } \\
\text { 始め, 徐々に教師のペースで活動 } \\
\text { するようにする.やりとりの中で } \\
\text { 指示学習の練習をする. }\end{array}$ & $\begin{array}{l}\text { 各教科 } \\
\text { (担任) } \\
\text { 算数（かず） } \\
\text { (佐藤) }\end{array}$ & $1 \sim 5$ \\
\hline $\begin{array}{l}\text { ○(3) 新しい担任に慣れ，一 } \\
\text { 緒に遊んだり意思表示を } \\
\text { したりする. }\end{array}$ & $\begin{array}{l}\text { ・担任と一緒に遊んだり,ゲ } \\
\text { 一ムをしたりする. 自分の } \\
\text { 要求を, 話し言葉や身振り } \\
\text { で伝える. }\end{array}$ & $\begin{array}{l}\text { ・一緒に遊んだり, ゲームを楽しん } \\
\text { だりする中で信頼関係を築く.や } \\
\text { りとりの中で, 指示学習の練習を } \\
\text { する. (身振りサイン) }\end{array}$ & $\begin{array}{l}\text { 日常生活 } \\
\text { （担任） }\end{array}$ & $1 \sim 5$ \\
\hline $\begin{array}{l}\text { (4) 担任や通常学級の担任 } \\
\text { にあいさつをする. }\end{array}$ & $\begin{array}{l}\text { ・「おはよう」「さようなら」 } \\
\text { 「ありがとう」「はい」など } \\
\text { のあいさつをする. }\end{array}$ & $\begin{array}{l}\text { ・教師のほうから積極的に声をか } \\
\text { け，あいさつを促す.できたとき } \\
\text { はほめる. }\end{array}$ & $\begin{array}{l}\text { 日常生活 } \\
\text { (担任, 通常 } \\
\text { 学級担任, } \\
\text { 佐藤) }\end{array}$ & $1 \sim 5$ \\
\hline
\end{tabular}

※@は最優先目標, ○は優先目標. 本表は, 実際の書式とは異なる.

※評価は, 5 たいへんよくできた, 4 よくできた, 3 できた, 2 あまりできなかった, 1 できなかった，の 5 段階の自己評価 とする。

る」(社会性）とし、新担任と信頼関係を構築するた め「新しい担任に慣れ、自分から話しかけたり一緒に 遊んだりする」(短期目標(4))、交流学習への負担を軽 減するため「5 年生の雲囲気に慣れ、特定の友だちと 一緒に活動する」（短期目標(5)）を設定した。

B 児の中心課題を、「横になったり座り込んだりす る行動を少なくする」に設定した。そして、長期目標 1 を「教師の声かけでスムーズに行動し、横になった り座り込んだりする行動を少なくする」（生活）とし、 教師の指示で活動できる回数を増やすため「教師の声
かけでランドセルの片づけ、給食の用意をする」(短 期目標(1)）を設定した。長期目標 2 を「いろいろな活 動をとおして興味や関心を広げ、いすに座って学習に 取り組む時間を徐々に延ばす」(学習) とし、着席行 動を身につけるために「1日に 1 回は着席して学習や 活動に取り組む」(短期目標(2) を設定した。長期目 標 3 を「話し言葉や動作、身振りなどで自分から友だ ちや教師にかかわろうとする」(社会性) とし、新担任 との信頼関係を構築するために「新しい担任に慣れ一 緒に遊んだり意思表示をしたりする」(短期目標(3)）、 
挨拶をとおして身近な人とかかわることを目指し「担 任や通常学級の担任に挨拶をする」（短期目標(4)）を 設定した。

3）指導内容・方法の設定：Table 3、4 に示す ように、教職員間の連携を図りつつ、身振りサインや ごほうびシールなどにより、対象児の意欲を引き出す ことにした。

4）個別の指導計画の提示：教職員への通信 『かけはし』により、個別の指導計画を提示した。そ して、校内研修会に抢いて、プロフィール、目標、指 導内容・方法、連携・支援体制等について説明し、共 通理解を図るとともに協力を依頼した。また、保護者 には、個別の通信『たんほほ iii』により、個別の指導 計画を提示した。

\section{2. 個別の指導計画の実践におけるコーディネータ 一の活動の実際}

（1）A 児、B 児に対する指導の実際と評価：学 習指導は、佐藤が算数を、障害児学級担任が算数以外 の各教科等を担当した。生活場面や交流学習（社会 性）等、学校生活全般については、障害児学級担任が おもに指導し、佐藤と他の教職員も関与した。このよ うに、指導面はコーディネーターが直接入り、常に障 害児学級担任と相談しながら実践した。また、評価は 1 学期、2 学期の指導を終えた時点で行い、短期目標 の修正や指導内容・方法の見直し等に生かし、指導の 改善につなげた。

Table 3 に示すように、A 児の長期目標 1 「体調の 変化に気づき、必要に応じて周りの教師や友だちに伝 えたり助けを求めたりする」は、1学期は、体調の変 化への対処の仕方について、担任と佐藤が日常生活の 中で繰り返し A 児に説明し、教材として絵本『あた まのなか』を用いた。その結果、自分から休息をとる ことができるようになった。2 学期は、体調の変化を 担任に伝えるために、合図（マカトンサインを参考 に、「右手のこぶしを胸の辺りに当てる」）を使うよう に指導した。その結果、合図をしたり、「先生…」と 呼びかけたりするようになった。

トイレ指導は、1学期は担任が、トイレに行く時刻 （9 時 30 分、 10 時 30 分）の設定、手づくり時計の製 作、教室の時計に 5 分刻みの表示の工夫をした。しか し、A 児は声かけや促しが必要で、自分から行くこ とはできなかった。2 学期は担任が、トイレに行く時 刻を『トイレタイム』と称し、1日のスケジュール表 に印をつけた。また、自分で行くことができたとき は、カードにごほうびシールを貼り賞賛した。その結
果、自分でトイレに行くようになり、排尿の失敗がほ とんどなくなった。なお、「行事参加の前に自分で卜 イレに行く」は指導の機会がなかったため、他の場面 で応用（汎化）することにした。

長期目標 2 の「学習に意欲的に取り組み、持続時間 を延ばす」は、1 学期終了時には教師の声かけで学習 を始め、20 分前後学習を持続することができた。ま た、2 学期終了時には自分から学習を始める場面がみ られ、学習持続時間は 30 分前後に延びた。佐藤の指 導する算数では、A 児の誌知処理様式を生かした指 導方略（五十嵐，2002）により、具体的操作で 5 まで の数の合成・分解、 5 を基礎とする 10 までの数の合 成・分解ができた。

長期目標 3 の「自分から進んで友だちや教師とかか わる」は、1学期は A 児担任や交流学級担任の仲立 ちで、給食交流時などに自分から近くの友だちに話し かけたり、話に加わったりするようになった。家庭で は、交流学級のD 児の話をよくするようになった。 また、2 学期は後述のA 児担任の出張授業により、 これまで参加したがらなかった交流学級での H 小祭 りの練習が、「5年生と一緒にしたら楽しかった」と いうように変わった。

2 学期の指導実践を終えた時点の聞き取り調査で、 A 児は、「しんどいときに先生に言った。トイレタイ ムに自分でトイレに行った」と告げた。また、保護者 は、「発作が起こっても恐怖心がなくなり、落ち着い てきた。楽しそうな顔で学校でしたことを話す」と述 べた。このことから、A 児の中心課題である「安心 して楽しい学校生活を送る」が達成されたと評価し た。

Table 4 に示すように、B 児の長期目標 1 「教師の 声かけでスムーズに行動し、横になったり座り込んだ りする行動を少なくする」については、1学期の指導 開始時は、声かけや促しでランドセルの片づけ、給食 の用意を指示したが、B 児は取りかかろうとしなかっ た。そこで、佐藤が $\mathrm{N}$ 附属養護学校の指導を参考に、 活動の手順を写真で提示することにした。また、1人 でできたときには、その場でごほうびシールを貼って ほめた。その結果、B 児は、1 学期終了時にはランド セルの片づけが自分でできた。しかし、給食のエプロ ンの着用については、写真の提示が必ずしも有効でな いことがわかった。そこで、2 学期は写真の提示と合 わせて、タイミングを見計らってエプロン着用の声か けをするとともに、ごほうびシールに改善を加えた。 その結果、B 児は、担任や佐藤の声かけでエプロンを 
着用することができた。

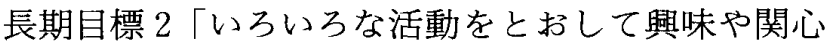
を広げ、いすに座って学習に取り組む時間を徐々に延 ばす」については、1 学期は B 児が一番興味をもって いる「こいのほり」を題材に絵や工作に取り組んだと ころ、着席行動が身につき、簡単な課題をやり遂げる ことができた。さらに、2 学期は担任の指示を聞いて 複数の課題に取り組むことができた。佐藤の指導する 「かず」の学習は、『認知発達治療の実践マニュアル』 （太田・永井, 2003）、『基礎をきずく』（林・米光, 2001） を参考にした。1 学期はクーダルバーンを教材として 用いた結果、着席して課題に取り組み、具体物を操作 して「1対 1 対応」ができた。学習持続時間が延び、 20 分以上にわたることがあった。また、2 学期は「1 と 2 の弁別、認知」に取り組み、具体物と数字カード をマッチングしたり数えたりできた。学習は、長いと きで 30 分近く持続できた。

長期目標 3 「話し言葉や動作、身振りなどで自分か ら友だちや教師にかかわろうとする」は、1学期は担 任が積極的に声をかけたことで、身振りなどで意思を 伝えることができた。「おはよう」の挨拶は気分に左 右され、言葉や身振りでできないときがあった。そこ で、2 学期はコーディネーターが教職員への通信『か けはし』で、通常学級担任に B 児への積極的な声か けを呼びかけた。その結果、B 児は言葉での挨鲜が増 え、「ありがとう」のほか、「ごめんなさい」「ごちそ うさま」がはっきり言えるようになった。名前を呼ば れたときには、身振りなどで返事をするようになっ た。家庭では、祖母に「おやすみなさい」と必ず声を かけ、児童クラブでは指導員に挨拶をするようになっ た。

2 学期の指導実践を終えた時点で、B 児は担任の声 かけや指示で行動できることが多くなった。また、身 振りや言葉での挨㩖をとおして、身近な人とのかかわ りができはじめた。だが、友だちとのかかわりは十分 でなく課題となった。B 児は長期目標 1 から 3 の達成 により、ベースライン期によくみられた、横になった り座り込んだりする行動がほとんどみられなくなっ た。また、保護者は聞き取り調查で、「家でも葠転ぶ ことがなくなった。言葉かけで動き出すようになっ た」と述べた。このことから、B児の中心課題である 「横になったり座り込んだりする行動を少なくする」 が達成されたと評価した。

（2）校内の連携・支援体制の実際と評価：コー ディネーターが、連携・支援体制について教職員の役
割（連携・支援内容）を明確にし、職員研修会や通信 『かけはし』をとおして教職員に提示した。そして、1 学期、2 学期の実践終了時に聞き取り調査を行い、連 携・支援体制に対するおのおのの役割の自己評価を求 めた。

1）交流学級担任の連携・支援内容：(1) 障害児 学級担任と交流学習の時間、内容・方法、役割分担な どについて連絡を取り合う、(2) 学級の児童へ障害理 解教育、人権教育を推進する。

B 児の交流学級の 6 年生担任は、昨年度から交流学 級担任としてかかわりがあり、支援内容が確立してい た。だが、A 児の交流学級の 5 年生担任ははじめて であり、連携・支援を図る必要があった。そこで、コ ーディネーター、障害児学級担任、5 年生担任で協議 を重ねた。

1 学期は、学習や行事、給食交流の仕方について綿 密な打ち合わせがされた。A 児の交流学級担任は、 学級の児童に対し、A 児への理解を深め仲間意識を もたせるために時間を設けて指導を行った。筆者ら は、これらのことから、交流学級担任との連携は十分 図れていると評価した。連携・支援体制をより強化す るために、「学習計画を早めに立て交流の機会を増や す」を課題とした。また、交流学級担任の「A 児担 任に、A 児の様子や気持ちなどを 5 年生児童に伝え てもらいたい」という意見を取り上げ、「A 児担任の 出張授業」を課題とした。コーディネーターが、これ らの課題を教職員への通信『かけはし』で提示し、各 担任と役割分担や改善策を協議した。

2 学期は、コーディネーターが同席し、夏休み中に 学習計画を検討したところ、家庭科や図工などで「交 流学習の機会を増やす」ことができた。「A児担任の 出張授業」は、コーディネーターの提言で、 $\mathrm{H}$ 小祭 りの前に実施した。A 児担任が 5 年生児童に、H 小 祭りに対するA 児の気持ちを話して理解を求めた。 その結果、A 児は 5 年生の児童とともに、練習に参 加することができた。

2 ）通常学級担任の連携・支援内容：(1) A 児、 B 児と学級の児童相互の安全確保の指導をする、(2) 学級の児童へ障害理解教育、人権教育を推進する。

1 学期の学級児童への指導は、廊下や階段の通り方 など「安全確保のための指導」が実践されたが、全学 級で時間を特設した障害理解教育、人権教育は行われ なかった。一方、 4 年生の担任は、生活場面で積極的 に障害理解教育、人権教育を行った。同担任は、2 年 前に B 児の交流学級担任として成果を上げており（緒 
方，2001）、本研究に执いては通常学級担任として、B 児に対するかかわり方を学級の児童に指導し、休み時 間など日常生活の中での自然な交流を支援した。しか し、他の通常学級担任には積極的な動きがみられなか ったため、「障害理解教育、人権教育の推進」を課題 とし、通信『かけはし』をとおして実践を呼びかけ た。

2 学期は、それぞれの学級の実態に応じた指導が行 われた。2 年生の担任は、能力差による差別や、仲間 はずしが許されないことを指導した。B児の弟が在籍 する 3 年生の担任は、どの子の個性も大事にしなけれ ばならないことを指導した。先述の 4 年生の担任は、 学級の児童が A 児、B児のことを正しく理解するた めに、学級内の仲間づくりの実践を行った。筆者ら は、これらの取り組みから、「人権教育の推進」はほ ぼ実践されたと評価した。しかし、人権学習、障害に 関する学習 (知識)、交流学習 (体験学習) の三本柱 からなる「障害理解教育の推進」(大久保, 1997) とい う点では十分ではなく、課題となった。

3 ）養護教諭の連携・支援内容：(1) 障害児学級 担任と常に連絡を取りながら、A 児、B児の健康状 態を把握し合い、必要な対応をする、(2)必要に応じ て主治医と連携を図る。

障害児学級担任は、1学期はA 児の体調不良時に すぐ対処してもらえたこと、ささいなことでも相談で きたことから、養護教諭との連携は十分であると捉え ていた。だが、養護教諭は、「A 児の普段の様子や家 庭での健康状態も把握する必要がある」と考え、担任 との連携が十分であると捉えていなかった。このよう に障害児学級担任との連携では、養護教諭という専門 職の目から見たときに、A 児の健康状態の把握の仕 方について相違がみられた。そこで、コーディネータ 一がこの点を課題として両者に伝え、役割を確認する ことで改善を試みた。さらに、保護者の意見から、A 児の体調を記入する「専用の連絡ノート」を作成し、 担任、保護者、養護教諭の三者間の意思疎通を図っ た。養護教諭は、2 学期の障害児学級担任との連携に ついて、「互いに児童の様子を話し合った」「家庭から の連絡事項や、子どもの体調について報告があり課題 はない」と肯定的な捉え方に変わった。

4) 管理職者の連携・支援内容：(1) 障害児学級 担任の報告から、 $\mathrm{A}$ 児、B 児の健康状態や様子を把 握する、(2) 必要に応じて障害児学級担任に指示をす る。

校長は障害児学級担任から児童の健康状態の報告を
受け、その都度適切な指示をした。また、自ら教室に 足を運び、担任や A 児、B児によく声をかけた。教 頭は A 児の授業を担当し、担任の出張時には積極的 に授業に入るなど普段から指導面でもかかわりをもっ た。B 児担任は、管理職者のこのような取り組みを、 「管理職者が理解してくれている」と肯定的に捉えて いた。

5 ）保護者との連携内容：(1) 緊急時の対応につ いて共通理解を図る、(2)送迎時の面談や連絡ノート の活用により、健康状態や活動の様子を伝え合う。

コーディネーターが連絡調整役を担い、個別の通信 『たん粱ぼii』により実践の様子や結果を伝え、願い を聞いた。その結果、保護者との連携に不可欠なこと として、A 児については健康状態や様子について伝 え合う、B児については学校での活動の様子を詳しく 伝えることが挙げられた。A 児に対しては、担任と、 先述の「専用の連絡ノート」の書式や記入の仕方を改 善した。その結果、担任は $\mathrm{A}$ 児の家庭での健康状態 がわかり教育活動に配慮ができる、保護者は学校での 様子がよくわかり安心する、といった双方向の効果が 得られた。また、B児に対しては、担任と連絡ノート への記入の仕方を改善したところ、保護者から「学校 での様子を多めに書いてくれるようになり、2 学期の ほうがわかった」という感想が得られた。

\section{IV. 考 察}

\section{1.コーディネーターの果たした役割}

本研究では、「複数の教師で取り組む」「教師間の協 力体制をつくる」ことを意図し、コーディネーターが 介在し、 $\mathrm{H}$ 小学校 $\mathrm{N}$ 障害児学級において個別の指導 計画を作成、実践した。その結果、A児、B 児の変 容のみならず、教師集団にも変容がみられた。以下、 おもな変容点について述べ、コーディネーターの役割 について考えてみたい。

1 学期と 2 学期の教職員による自己評価を比較する と、教職員の意識は 3 から $4 、 4$ から 5 といったよう に高まっていた。最も変容がみられたのは障害児学級 担任であり、A 児担任は自己評価が 3 から 4 へと変 わった。教職 2 年目の同担任は、今年度 $\mathrm{H}$ 小学校に 赴任し、はじめて障害児学級担任になり、当初は不安 な思いをもっていた。だが、コーディネーターが個別 の指導計画を提示し仲立ちをしたことで、1学期終了 時には、「障害児学級担任間の連携が児童を支援する うえで役立った」と感じていた。さらに、コーディネ ーターが交流学級担任や通常学級担任との連携強化を 
働きかけたことで、2 学期終了時には、「周りの先生 方と一緒にがんばっていきたい」という前向きな気持 ちへと変化した。このような変化には、個別の指導計 画を作成し、複数の教員で取り組んだことが関与して いたと考えられた。また、指導力や技量の向上に教育 的効果がみられ、目標を立て指導実践していくことの 意義、教材研究や指導内容・方法の工夫の必要性に気 づくなど、教師自身の成長をもたらした。この点に関 しては、前年度の障害児学級担任との引継ぎが十分で なかったことを踏まえて、コーディネーターが一緒に 教材研究をしたことの意義が大きかったといえよう。

$B$ 児担任は扝もに、6 年生の担任、教務主任として 校内全体にかかわる職務を遂行してきた。同担任の自 己評価は、1、2学期ともに 4 で数值上の変化はなか ったものの、全教職員による子どもへの働きかけの重 要性について考えるようになった、障害児学級担任の 視点から校内全体をみるようになった、といった気持 ちの変化がみられた。これは、個別の指導計画の作 成、実践において、コーディネーターが連携・支援体 制を重視したことが関与していたためと思われた。同 担任は、「教師は 1 人で問題を抱え込む習性があるが、 本校は校内の雾囲気がよいので交流学級担任にも頼み やすい」と述べ、校内の連携・支援体制が効果的に機 能したと認識していた。

交流学級の 5 年生担任の自己評価は、4 から 5 へと 高まった。同担任は、「A 児と教室が離れていても一 緒と思えるような学級にしょう」と教師の思いを発信 し、A 児を学級の一員と意識して指導した。その結 果、A 児に対してだけでなく、5 年生児童相互のかか わり方も変わっていった。特定の友だちどうしでなく 互いにかかわるようになり、これまで1人でいること の多かった $\mathrm{E}$ 児や $\mathrm{F}$ 児にも声をかけるようになった。 $\mathrm{A}$ 児との交流を通して学級経営上の課題が克服され ていったのは、障害児学級担任との連携が十分図られ たことによるものと考えられた。

通常学級担任では、自己評価が高まったのは 4 年生 担任で、2.5から 3 となった。他の担任は、数値上の 変化はなかったものの、実際のかかわり方において次 の上うな変容がみられた。教職 2 年目ではじめて障害 児に接した 2 年生の通常学級担任は、1 学期は「どう 接したらよいかわからない」と述べていたが、2 学期 は $\mathrm{A}$ 児や $\mathrm{B}$ 児に自然に話しかけていた。また、 3 年 生の担任は、1 学期は「B児にかかわっていかなけれ ばと思うが、B 児の状況がわからずかかわり方が難し い」と述べていた。しかし、2 学期はB $\mathrm{B}$ 児を朝会に誘
ったり、話しかけたりと積極的にかかわった。このよ うに、A 児、B児にはじめて接した通常学級担任に も、個別の指導計画の実践をとおして意識の変容が認 められた。

養護教諭は、自己評価が 2.5 から 3.5 へと変わっ た。同教諭は、前年度から校内の連携を課題に挙げて いた。今年度は、職員間で児童の様子や緊急時の共通 確認をしたこと、管理職者が障害児学級担任や養護教 諭の動向に気をつけていることから、前年度より連携 が図られたと捉えるようになった。

ここで、コーディネーターの果たした役割について 整理すると、指導面では障害児学級担任と一緒に児童 の指導にあたり、指導内容・方法、教材研究等につい て具体的なアドバイスを行った。障害児学級担任間の 引継ぎという点では、個別の指導計画を提示し、児童 の指導にあたった。連携・支援の面では、教職員の役 割分担を提示して連携・支援内容を明確に示し、実践 後に聞き取り調査を行い、自己評価を求め自己の振り 返りを促した。また、情報交流として、教職員に通信 『かけはし』を発信した。こういったコーディネータ 一の活動が、前述の各担任、養護教諭の意識の変容を もたらし、あわせて $\mathrm{H}$ 小学校の連携・支援体制づく りに大きく貢献したといえよう。

特別支援教育では、コーディネーターの役割が重要 だといわれている（特別支援教育の在り方に関する調 查協力者会議, 2003)。現行では、校内の障害児学級担 任がその任に就くことが多い。今回、佐藤は、元 N 障害児学級担任であり、現職派遣の大学院生という立 場でコーディネーター役を担った。校内にいる時間が 限られるため、情報交換の手段として聞き取り調查を 行った。この聞き取り調查により、教育現場で設けに くいといわれている教師間や保護者との話し合いの場 をもつことができた。そして、双方向の意見交換を可 能にし、N 障害児学級の A 览、B 児に対する教職員 の関心が高まった。したがって、本研究の結果から、 連絡調整役の役割として、個々の教師間にとどまら ず、校内の連携・支援体制づくりを目指すことが重要 であるといえる。

さらに、今回、コーディネーター自身が実際の指導 に当たったことで、連絡調整役としてだけでなく、次 のような意義を見いだせた。(1)実践課題を把握でき、 共通の問題意識をもつことができる。(2)具体的な指 導内容・方法、教材研究をともに実践し検討すること ができる。したがって、校内の教師がコーディネー夕 一になったときに留意することは、第三者としての客 
観的立場（連絡調整役）と、教員集団の一員としてと もに実践を行うといった協働意識をもつ必要があろ う。そして、協働意識をもつうえで、個別の指導計画 の作成、実践が有効であろう。

\section{2. コーディネーター介在の効果}

コーディネーターが介在することによって、次のよ うな効果が得られた。(1) 障害児学級担任以外の教師 にも、個別の指導計画の作成や実践の意義が理解され 波及していった。(2)管理職者の支持と理解のもと、 $\mathrm{A}$ 児、B 児の変容はもとより、各担任、交流学級や 通常学級の児童、保護者おのおのの意識の変容がみら れた。その結果、校内の連携・支援体制が強化され た。

このような校内の連携・支援体制について、A 児 の保護者は、「校内全体で課題に取り組んでいるので、 他の先生方も A 児のことを理解してくれている。A 児の存在感があり、居場所がある」とすべての教職員 がかかわってくれていると感じていた。また、B児の 保護者は、B児の成長の様子から、「ここまでしても らえるとは思わなかった。充実した年であり、最後の 1 年だったのでよかった」という感想を述べていた。 このように、保護者との信頼関係が深まったのは、各 担任がおの扔のの役割を認識し、協力して連携・支援 体制を組み、子どもを多面的に捉え支援していくこと ができたためであろう。

以上のことから、コーディネーターが介在した効果 が認められ、コーディネーターの重要性が実証でき た。

\section{V ．おわりに（今後の課題）}

本研究の課題として、まず第 1 に、障害理解教育が 浸透していないために（篠原, 1998）、教職員の意識や 指導力に違いがみられたことが挙げられる。そのた め、コーディネーターが介在して個別の指導計画を作 成・実践したことで教職員に変容がみられたものの、 自己評価の数值にばらつきがあった。そこで、教育課 程に障害理解教育を位置づけて（三上・高橋，1994）、 専門的な知識や具体的な方法を教職員に提示し、共通 の意識と指導力の向上を図り自己評価の数值を高め、 校内の連携・支援体制を構築していきたい。

第 2 に、本研究は、障害児学級に在籍する知的障害 児を対象としていた。そのため、本研究におけるコー ディネーターの役割は、通常学級に在籍する LD、
ADHD、高機能自閉症等の児童への教育的支援と直 接的にかかわるものではなかった。今後、本研究の結 果を踏まえ、障害のある児童 1 人 1 人の教育的ニーズ に応じたコーディネーターの役割を検討していきた い。

\section{謝 辞}

本研究を進めるにあたり、 $\mathrm{H}$ 小学校の教職員の皆 様、対象児童および保護者の方に多大なご協力をいた だいた。ここに記してお礼を申しあげる。

\section{付 記}

本研究は、筆頭著者 (佐藤) が、鳴門教育大学大学 院学校教育研究科に提出した平成 15 年度修士論文 （2003）の一部を再構成したものである。

\section{文 献}

安藤隆男 (2002) 第 5 章 個別の指導計画の目的論. 安藤隆男 (編著), 自立活動における個別の指導計画 の理念と実践. 川島書店, 75-86.

林 邦雄・米光みつ子（2001）基礎をきずく.コレー ル社, 18-23.

五十嵐靖夫（2002）第 3 章 算数の基礎に関する指 導. 藤田和弘 - 青山真二 - 熊谷恵子 (編著), 長所活 用型指導で子どもが変わる. 図書文化社, 104-106.

笠原芳隆（2002）第 4 章 個別の指導計画作成の現状 と課題. 安藤隆男 (編), 自立活動における個別の指 導計画の理念と実践. 川島書店, 55-69.

三上たみ・高橋 智（1994）障害理解教育実践の研究 一大阪府立富田林市立富田林小学校の「発達・障 害・障害者問題学習」実践を事例に一. 日本社会福 祉学会第 42 回全国大会報告要旨集, 596-597.

緒方郁恵 (2001) 徳島県 $\mathrm{N}$ 市の障害児学級における 交流教育の実態. 鳴門教育大学大学院修士論文.

大久保哲夫 (1997) 障害理解教育の展開と課題. 清水

貞夫 (編)，障害児教育学. 全障研出版部, 152 .

太田昌孝・永井洋子（2003）認知発達治療の実践マニ ユアル．日本文化科学社, 4-46.

篠原真由美（1998）小学校における障害理解教育の実 践的研究. 鳴門教育大学大学院修士論文.

特別支援教育の在り方に関する調査協力者会議 (2003) 今後の特別支援教育の在り方について（最終報告）. -2004.7.23 受稿, 2005.12.3 受理一 